\title{
Competition Frame on MotoGP Articles: A Cognitive Linguistic Approach
}

\author{
Yessy Purnamasari \\ English Education Study Program, Faculty of Education and Teacher Training \\ Universitas Suryakancana, Cianjur, Indonesia \\ E-mail: yessy@unsur.ac.id
}

\begin{abstract}
This paper is entitled "Competition Frame on MotoGP Articles: A Cognitive Linguistic Approach." This research is aimed to identify two main points: (1) the elements of the competition frame found in MotoGP articles and (2) to identify the most frequent element that occurs in MotoGP articles. This research employs the syntactic approach and uses the descriptive qualitative method. The siginificance of this study is to give information about the competition frame on sport articles as part of linguistic variety. The result of this research shows there are six elements used on the articles: competition, participant, place, prize, rank and score and value. Then, the most frequent words that occur on the MotoGP articles are dominated by the participant elements $(92.85 \%)$ and rank and score elements $(28.57 \%)$.
\end{abstract}

Key words: frame semantic, cognitive linguistics, competition element

\section{INTRODUCTION}

Recently, the theory about Frame Semantics composed by Fillmore in 1976 has gained many interests from many researchers. He discovered that our thought is organized by what is called as mental structures. He also pinpointed that words are mentally defined by their frame structures. In relation to this theory, the basic example includes the semantic field which refers to these words: buy-sell-goods-price-cost.

In this case, those words are defined by their commercial event frame. A seller, for example, means as the person who has properties and wants to trade them with money meanwhile the one who own the money and will to trade it for properties is called as a buyer. Both of them have the mutual exchange. Furthermore, goods refers to those properties exchanged and price refers to the money itself. These are what we call as "semantic roles" which is the conceptual elements of the frame (Lakoff, 2014).

According to Lakoff (2014), there are five focus which become the center of frame semantics : the frames that are used for forming our experience; the semantic roles and scenarios which interpret each frame; the words that are interpreted by the frames; the 
grammar associated with the frame elements; and the mechanism of how frames connect to one another.

One of interesting points that becomes the concern of the writer is the competition frame used in a sport article. The main point of the sport article is focused on the article which reports the MotoGP competition. According to the official website of MotoGP, MotoGP is a motorcycle race series world championship which visits more than ten countries during the season which is aired in television. The news about MotoGP used as the data source in this research is taken from www.motorsport.com. As this is a sport article, there must be words that evoke the competition frame, such as lose, win, defeat, come in, play, and etc.

This study tries to acknowledge the use of Frame Semantics on text. Thus, the analysis is more focused on analysing the sport competition frame on MotoGP articles. In the theory of Frame Semantics, word meanings are interpreted in proportion based on the frames.

There are numbers of website which provides online articles about MotoGP. For this research, the writer chooses the articles from www.motorsport.com to be the data source. As part of Motorsport Network Company, this website was formed in 1994 and Motorsport.com declares itself as an adavanced digital platform which specifies itself in the content about motor racing which provides 21 editions in 14 languages.

This research is expected to be useful for the writer and the readers in general. This research is using the frame semantic analysis to find out what are the characteristics and elements of sport competition frame on MotoGP articles. The frame semantics by Fillmore will make the writer be able to analyse the language comprehensively while the Kovecses's competition frame helps the writer to analyse through the elements of the frame.

For the linguistic studies, the theoretical benefit of this research is to give information about the competition frame on sport articles. In addition, this research also contributes as the reference for another research. Moreover, this research is expected to be a useful source as the explanation provided on this research will be focus on frame semantics.

The writer focuses the analysis on the following formulations: 
1. What elements of the competition frame found in MotoGP articles?

2. What is the most frequent element that occurs in MotoGP articles?

The research objectives are:

1. to identify the elements of the sport competition frame found in MotoGP articles.

2. to identify the most frequent element of the sport competition frame found in MotoGP articles.

\section{LITERATURE REVIEW}

The theory of Frame Semantics was developed by Charles Fillmore in 1970s. He defines Frame Semantics as an approach to the study of lexical meanings (Fillmore et al. 2003).

Fillmore comes to a supposition that any word in any kind of language is mentally interpreted by elements of such mental structures known as "frames." The important notion of this theory is that "word meanings must be described in relation to semantic frames - schematic representations of the conceptual structures and patterns of beliefs, practices, institutions, images, etc. that provide a foundation for meaningful interaction in a given speech community" (Fillmore et al. 2003:235). In short, a semantic frame is the structure of knowledge which is required to comprehend a certain word or even related group of words.

Thus, Frame Semantics investigates how linguistic forms capture the frame knowledge and how the frames then be possibly merged into a comprehension of pieces containing those forms (Fillmore \& Baker, 2009: 317).

The basic unit of knowledge in psychology is concept. One basic example is the idea of car. It has a field of characteristics that relates to its parts (wheels, tires, windscreen, etc.), as well as that it requires petrol or diesel to work, and should be driven by humans who already have the driving license. While we know how this concept works, there is still no clear scheme of representing the relationships amid the components. Consequently, frame theory is required to conquer this defect. In relation with that, two fundamental elements of frames are attribute-value sets and structural invariants. 
Barsalou (as cited in Citraresmana, 2016:224) defines attribute as a concept that represents one aspect of a larger whole. Meanwhile, values are subordinate concepts which represent subtypes of an attribute. Generally, values tend to be more specified than the attributes because it can have subtypes.

Humans have the capacity to visualize or replicate the conceptual unit based on a distinct frame. For example, we are able to replicate the phases of loading up the car with patrol, which begins by taking the petrol cap off until putting back the cap after the petrol is full.

Competition frame is a type of semantic frame which consist of number of elements: the competition, participant, prize, and so on. The frame names are usually written in the Courier typeface. These elements are associated by certain events, such as lose, win, defeat, and so on.

This frame focuses with the notion that people (Participant_1, Participant_2, or Participants) takes part in an well regulated procedure administered the activity (the Competition) to accomplish several beneficial result. Rank and Score are contrastive standard where the level of attainment of the beneficial result is appraised. The following is the example taken form the FrameNet website:

\section{1. [Tracy]Participant_1 PARTICIPATED [against Joe]Participant_2 [at badminton]Competition.}

2. [Tracy and Lindsay]Participants PARTICIPATED [at badminton]Competition.

The verbs lose, play, defeat link the elements in the frame and take particular elements in particular order, sometimes using additional prepositions. For example, a participant can lose to a competition, a participant can lose to another participant, and a competition can be lost, but a participant cannot be lost or a participant cannot lose to another participant. Such sentences evoke the entire frame of competition (Kovacses, 2006).

Kovecses (2006) identifies the elements of competition frame. Those elements are:

1. Competition: name of competition

2. Participants: take part in activity (competition) to gain beneficial results 
3. Place: where the event take places

4. Prize: the reward to the winner of a competition

5. Rank and Score: contrastive standard where the level of attainment of the beneficial result is appraised

6. Venue: the venue of the competition

\section{METHODOLOGY}

This research uses descriptive qualitative method which goal is to make a comprehensive summarization (Lambert \& Lambert, 2012). The study focuses on revealing the competition frame on MotoGP articles by identifying elements and the characteristics of frame semantic of Fillmore. The texts on the sports articles about MotoGP, which becomes the data source, are taken from the website of Motorsport.com which can be accessed through www.motorsport.com. The whole texts are marked, copied, analysed by using the competition frame element of Kovecses. The steps of the research consist of:

1. collecting the data

2. sorting the data

3. analyzing the data

4. presenting the result and conclusion

As there are many ways for analysing the frame semantics, this research employs the frame semantic theory by Fillmore and the analytic tools employ the Kovecses's competition frame elements (competition, participants, place, prize, rank, score, and venue).

\section{RESULTS AND DISCUSSION}

This research is mainly done to seek for the competition frame elements found in the articles about MotoGP. To do so, the main data source for this research is all taken randomly from the www.motorsport.com that produces any kind of news articles 
regarding to sport. In this case, the limitation is the research will more focus on the articles that report the MotoGP activities. Below is how the findings of the research are provided on a list of table:

Article 1: Vinales: Argentina was my best race yet in MotoGP

\begin{tabular}{|c|c|c|c|c|c|c|c|}
\hline \multirow{2}{*}{ NO } & \multirow{2}{*}{ SENTENCES } & \multicolumn{6}{|c|}{ COMPETITION FRAME ELEMENTS } \\
\hline & & Competition & Participants & Place & Prize & Rank\&Score & Venue \\
\hline 1 & $\begin{array}{l}\text { Suzuki rider Maverick } \\
\text { Vinales feels his showing in } \\
\text { last weekend's Argentinian } \\
\text { GP was his best yet since } \\
\text { graduating to MotoGP, } \\
\text { despite crashing out. }\end{array}$ & MotoGP & $\begin{array}{l}\text { Maverick } \\
\text { Vinales }\end{array}$ & Argentina & - & - & $\begin{array}{l}\text { Argentinian } \\
\mathrm{GP}\end{array}$ \\
\hline 2 & $\begin{array}{l}\text { Vinales had been closing } \\
\text { down Valentino Rossi in the } \\
\text { fight for second at Termas } \\
\text { de Rio Hondo, and was set } \\
\text { for his maiden premier } \\
\text { class podium before } \\
\text { crashing out on a damp } \\
\text { patch at Turn } 1 \text { with three } \\
\text { laps to go. }\end{array}$ & - & $\begin{array}{l}\text { Vinales; } \\
\text { Valentino } \\
\text { Rossi }\end{array}$ & - & $\begin{array}{l}\text { premier } \\
\text { class } \\
\text { podium }\end{array}$ & 2nd position; & $\begin{array}{l}\text { Tarmas de } \\
\text { Rio Hondo }\end{array}$ \\
\hline 3 & $\begin{array}{l}\text { Notwithstanding the } \\
\text { disastrous end to his race, } \\
\text { the Spaniard - who is yet to } \\
\text { finish higher than sixth in a } \\
\text { MotoGP race - said his } \\
\text { performance was the } \\
\text { strongest of his top-line } \\
\text { career so far. }\end{array}$ & MotoGP & the Spaniard & - & - & 6th position & - \\
\hline 4 & $\begin{array}{l}\text { "I believe it was my best } \\
\text { race in MotoGP," said } \\
\text { Vinales. }\end{array}$ & MotoGP & Vinales & - & - & - & - \\
\hline 5 & $\begin{array}{l}\text { "I was fighting for the } \\
\text { podium and with a great } \\
\text { pace, so for the moment } \\
\text { I'm happy and positive for } \\
\text { [the next race in] Austin. }\end{array}$ & - & I (Vinales) & - & - & podium & Austin \\
\hline 6 & $\begin{array}{l}\text { "Of course I thought I could } \\
\text { pass Rossi - }\end{array}$ & - & $\begin{array}{l}\text { I (Vinales); } \\
\text { Rossi }\end{array}$ & - & - & - & - \\
\hline 7 & $\begin{array}{l}\text { I was much faster than him } \\
\text { and I think I had the pace to } \\
\text { overtake him. }\end{array}$ & - & $\begin{array}{l}\text { I (Vinales); him } \\
\text { (Rossi) }\end{array}$ & - & - & - & - \\
\hline
\end{tabular}




\begin{tabular}{|c|c|c|c|c|c|c|}
\hline 8 & $\begin{array}{l}\text { "The result it's a shame, but } \\
\text { I'm really happy that we } \\
\text { showed our potential. }\end{array}$ & - & $\begin{array}{l}\text { I (Vinales); we } \\
\text { (Vinales and } \\
\text { his team) }\end{array}$ & - & - & \\
\hline 9 & $\begin{array}{l}\text { We're not ready to be in } \\
\text { the podium, but we took } \\
\text { the bike beyond the limit." }\end{array}$ & - & $\begin{array}{l}\text { We (Vinales } \\
\text { and his team) }\end{array}$ & - & podium & \\
\hline 10 & $\begin{array}{l}\text { He added: "Our target was } \\
\text { the top six. }\end{array}$ & - & $\begin{array}{l}\text { He (Vinales); } \\
\text { our (Vinales } \\
\text { and his team) }\end{array}$ & - & top six & \\
\hline 11 & $\begin{array}{l}\text { It was like that this time, } \\
\text { we had good pace. }\end{array}$ & - & $\begin{array}{l}\text { we (Vinales } \\
\text { and his team) }\end{array}$ & - & - & \\
\hline 12 & $\begin{array}{l}\text { We took advantage and I } \\
\text { was really taking } 100 \\
\text { percent of my bike. }\end{array}$ & - & $\begin{array}{l}\text { we (Vinales } \\
\text { and his team); } \\
\text { I (Vinales) }\end{array}$ & - & - & \\
\hline 13 & $\begin{array}{l}\text { Asked if the peculiar } \\
\text { circumstances of the } \\
\text { Argentina race, which } \\
\text { featured a compulsory bike } \\
\text { swap, played a part in his } \\
\text { competitiveness, Vinales } \\
\text { simply said: }\end{array}$ & - & Vinales & Argentina & - & \\
\hline 14 & $\begin{array}{l}\text { "My pace was really fast, } \\
\text { very similar to Marc } \\
\text { [Marquez]'s and } \\
\text { Valentino's, who I think } \\
\text { were both really quick". }\end{array}$ & - & $\begin{array}{l}\text { Marc } \\
\text { Marquez; } \\
\text { Valentino; I } \\
\text { (Vinales) }\end{array}$ & - & - & \\
\hline
\end{tabular}

If we analyze those sentences by using the competition frame elements and adapted the FrameNet theory, they are analysed as follow:

1. [Suzuki rider Maverick Vinales] $]_{\text {participant__ }}$ feels his showing in [last weekend's Argentinian GP] venue was his best yet since graduating to [MotoGP] $]_{\text {competition, }}$ despite crashing out.

2. [Vinales] participant_1 had been closing down [Valentino Rossi] participant_2 in the fight for second $\mathrm{rank}_{\text {and }}$ score at [Termas de Rio Hondo] venue, and was set for his maiden [premier class podium] $]_{\text {prize }}$ before crashing out on a damp patch at Turn 1 with three laps to go. 
3. Notwithstanding the disastrous end to his race, [the Spaniard] participant_1 - who is yet to finish higher than [sixth] rank and score in a [MotoGP] participant_1 race-said his performance was the strongest of his top-line career so far.

Article 2: Dovizioso says Iannone last-corner crash "unacceptable"

\begin{tabular}{|c|c|c|c|c|c|c|c|}
\hline \multirow{2}{*}{ NO } & \multirow{2}{*}{ SENTENCES } & \multicolumn{6}{|c|}{ COMPETITION FRAME ELEMENTS } \\
\hline & & Competition & Participants & Place & Prize & Rank\&Score & Venue \\
\hline 1 & $\begin{array}{l}\text { Andrea Dovizioso said that } \\
\text { Ducati factory teammate } \\
\text { Andrea lannone crashing } \\
\text { into him late in the } \\
\text { Argentine Grand Prix was } \\
\text { "unacceptable". }\end{array}$ & - & $\begin{array}{l}\text { Andrea } \\
\text { Dovizioso; } \\
\text { Andrea } \\
\text { lannone }\end{array}$ & - & - & - & $\begin{array}{l}\text { Argentine } \\
\text { Grand Prix }\end{array}$ \\
\hline 2 & $\begin{array}{l}\text { Dovizioso and lannone } \\
\text { appeared on course to } \\
\text { complete the podium } \\
\text { behind race winner Marc } \\
\text { Marquez before lannone } \\
\text { lost control of his bike and } \\
\text { crashed into his teammate } \\
\text { in the final corner of the } \\
\text { last lap. }\end{array}$ & - & $\begin{array}{l}\text { Dovizioso; } \\
\text { lannone; } \\
\text { Marc Marquez }\end{array}$ & - & - & - & - \\
\hline 3 & $\begin{array}{l}\text { As a result, Dovizioso had } \\
\text { to walk his damaged bike } \\
\text { over the finish line, } \\
\text { claiming } 13 \text { th place, } \\
\text { lannone being handed a } \\
\text { three-place grid penalty for } \\
\text { causing the incident. }\end{array}$ & - & $\begin{array}{l}\text { Dovizioso; } \\
\text { lannone }\end{array}$ & - & - & 13th place & - \\
\hline 4 & $\begin{array}{l}\text { "To lose these points for us } \\
\text { is a disaster," Dovizioso said } \\
\text { after the race. }\end{array}$ & - & Dovizioso & - & - & - & - \\
\hline 5 & $\begin{array}{l}\text { "[We could] be second in } \\
\text { the championship behind } \\
\text { Marquez, one point } \\
\text { [behind]... }\end{array}$ & - & We; Marques; & - & - & second & - \\
\hline 6 & $\begin{array}{l}\text { it was very important for } \\
\text { the championship because } \\
\text { it's how I approach the } \\
\text { race, how I approach the } \\
\text { season - to take the best } \\
\text { result for the } \\
\text { championship, to get the }\end{array}$ & - & I & - & - & - & - \\
\hline
\end{tabular}




\begin{tabular}{|c|c|c|c|c|c|c|c|}
\hline & $\begin{array}{l}\text { best result for the } \\
\text { championship. }\end{array}$ & & & & & & \\
\hline 7 & $\begin{array}{l}\text { "And this is, I think, the way } \\
\text { to approach everything } \\
\text { when you are in a factory } \\
\text { team and you want to get a } \\
\text { good result. }\end{array}$ & - & 1 & - & - & - & \\
\hline 8 & $\begin{array}{l}\text { Because we worked really } \\
\text { hard in the last two years } \\
\text { and we really created a } \\
\text { good bike, together. }\end{array}$ & - & we & - & - & - & \\
\hline 9 & $\begin{array}{l}\text { "And to lose the points like } \\
\text { this is unacceptable. } \\
\text { Unacceptable." }\end{array}$ & - & - & - & - & - & . \\
\hline 10 & $\begin{array}{l}\text { Dovizioso did say that there } \\
\text { were plenty of positives to } \\
\text { from the Italian } \\
\text { manufacturer's weekend in } \\
\text { Argentina. }\end{array}$ & - & Dovizioso & Argentina & - & - & . \\
\hline 11 & $\begin{array}{l}\text { "This weekend was very } \\
\text { difficult for everybody - and } \\
\text { we were able to manage } \\
\text { the situation," he said. }\end{array}$ & - & we & - & - & - & . \\
\hline 12 & $\begin{array}{l}\text { "We were very competitive } \\
\text { in qualifying, we start on } \\
\text { the second row and it was } \\
\text { perfect. }\end{array}$ & - & we & - & - & -- & \\
\hline 13 & $\begin{array}{l}\text { And we [would've been] } \\
\text { able to finish second in the } \\
\text { race. }\end{array}$ & & we & & & 2nd position & \\
\hline 14 & $\begin{array}{l}\text { It was perfect, we were } \\
\text { able to catch Valentino } \\
\text { [Rossi] and beat him - for } \\
\text { the championship it was } \\
\text { really important. }\end{array}$ & championship & $\begin{array}{l}\text { we; Valentino } \\
\text { Rossi }\end{array}$ & - & - & - & . \\
\hline
\end{tabular}

If we analyze those sentences by using the competition frame elements and adapted the FrameNet theory, they are analysed as follow: 
1. [Andrea Dovizioso] participant_1 said that Ducati factory teammate [Andrea Iannone] participant_2 crashing into him late in the [Argentine Grand Prix] venue was "unacceptable".

2. [Dovizioso] participant_1 and [Iannone] participant_2 appeared on course to complete the podium behind race winner [Marc Marquez] participant_3 before Iannone lost control of his bike and crashed into his teammate in the final corner of the last lap.

3. As a result, [Dovizioso] participant_1 had to walk his damaged bike over the finish line, claiming [13th place] rank and score, [Iannone] participant 2 being handed a three-place grid penalty for causing the incident.

ARTICLE 3: Rossi rues second bike struggles in two-part Argentina race

\begin{tabular}{|c|c|c|c|c|c|c|c|}
\hline \multirow{2}{*}{ NO } & \multirow{2}{*}{ SENTENCES } & \multicolumn{6}{|c|}{ COMPETITION FRAME ELEMENTS } \\
\hline & & Competition & Participants & Place & Prize & $\begin{array}{c}\text { Rank\& } \\
\text { Score }\end{array}$ & Venue \\
\hline 1 & $\begin{array}{l}\text { Valentino Rossi was left } \\
\text { lamenting a lack of feeling } \\
\text { on his second bike that left } \\
\text { him powerless to stop } \\
\text { MotoGP rival Marc } \\
\text { Marquez romping to victory } \\
\text { in Argentina. }\end{array}$ & MotoGP & $\begin{array}{l}\text { Valentino } \\
\text { Rossi; Marc } \\
\text { Marquez }\end{array}$ & Argentina & - & -- & - \\
\hline 2 & $\begin{array}{l}\text { With the weekend's tyre } \\
\text { drama causing the Termas } \\
\text { de Rio Hondo race to be } \\
\text { split in two parts by a } \\
\text { mandatory bike swap, } \\
\text { Rossi's race ended up being } \\
\text { one of two halves. }\end{array}$ & - & Rossi & - & - & - & $\begin{array}{l}\text { Termas de } \\
\text { Rio Hondo }\end{array}$ \\
\hline 3 & $\begin{array}{l}\text { In the opening phase, he } \\
\text { had the pace to keep up } \\
\text { with Marquez, and made } \\
\text { his pitstop right on the } \\
\text { Spaniard's tail after battling } \\
\text { hard for several laps. }\end{array}$ & - & he; Marquez & - & - & - & - \\
\hline
\end{tabular}




\begin{tabular}{|c|c|c|c|c|c|c|c|}
\hline 4 & $\begin{array}{l}\text { But Rossi said he simply } \\
\text { couldn't replicate his early } \\
\text { pace on the second bike, } \\
\text { allowing Marquez to escape } \\
\text { and bringing the Yamaha } \\
\text { rider into a fierce duel for } \\
\text { the runner-up spot. }\end{array}$ & - & $\begin{array}{l}\text { Rossi; } \\
\text { Marquez }\end{array}$ & - & & runner up & \\
\hline 5 & $\begin{array}{l}\text { "In the end it was a shame, } \\
\text { because in the first part I } \\
\text { was a lot stronger, so I } \\
\text { thought I could fight for the } \\
\text { win," said Rossi. }\end{array}$ & - & I & - & & - & \\
\hline 6 & $\begin{array}{l}\text { "For some reason on the } \\
\text { second bike, with the } \\
\text { second set of tyres, I don't } \\
\text { feel good, I had a lot of } \\
\text { problem making the same } \\
\text { pace. }\end{array}$ & - & I & - & & - & \\
\hline 7 & $\begin{array}{l}\text { "The conditions were very } \\
\text { bad and I was never able to } \\
\text { get into a rhythm, and in } \\
\text { the end [Maverick] Vinales } \\
\text { and the two Ducatis arrive } \\
\text { [on my tail]." }\end{array}$ & - & I; Vinales & - & & - & \\
\hline 8 & $\begin{array}{l}\text { "I thought the podium was } \\
\text { over" }\end{array}$ & - & - & - & & podium & \\
\hline 9 & $\begin{array}{l}\text { While Vinales crashed out } \\
\text { before he was able to make } \\
\text { a move on Rossi stick, } \\
\text { factory Ducati duo Andrea } \\
\text { lannone and Andrea } \\
\text { Dovizioso's both passed the } \\
\text { nine-time champion late } \\
\text { on. }\end{array}$ & - & $\begin{array}{l}\text { Vinales; } \\
\text { Andrea } \\
\text { lannone; } \\
\text { Andrea } \\
\text { Dovizioso's; } \\
\text { nine time } \\
\text { champion }\end{array}$ & - & & - & \\
\hline 10 & $\begin{array}{l}\text { With a lap-and-a-half to go } \\
\text { at Turn } 5 \text { I went very deep } \\
\text { and both me and lannone } \\
\text { went wide, Dovizioso went } \\
\text { past both of us and I } \\
\text { thought the podium was } \\
\text { over from me," he added. }\end{array}$ & - & I; Dovizioso & - & & podium & \\
\hline 11 & $\begin{array}{l}\text { "But at the last corner the } \\
\text { Ducati riders go out [after } \\
\text { hitting one another], so } \\
\text { these } 20 \text { points are like } \\
\text { gold for the championship." }\end{array}$ & championship & Ducati riders & - & & 20 points & \\
\hline
\end{tabular}




\begin{tabular}{|l|l|l|l|l|l|l|l|}
\hline 12 & $\begin{array}{l}\text { Rossi also said he felt the } \\
\text { race could have gone the } \\
\text { full distance without the } \\
\text { need for bike swapping, but } \\
\text { said overnight rain was a } \\
\text { bigger problem as the } \\
\text { Yamaha struggled in low- } \\
\text { grip conditions. }\end{array}$ \\
\hline 13 & $\begin{array}{l}\text { "For me we could have } \\
\text { done the whole race } \\
\text { without any problem, we } \\
\text { could do 25 laps [on one } \\
\text { set of tyres]," he said. }\end{array}$ \\
\hline 14 & $\begin{array}{l}\text { "But for safety reasons, it's } \\
\text { ok like this. }\end{array}$ & - & we & - & - & - & - \\
\hline 4 & $\begin{array}{l}\text { But Rossi said he simply } \\
\text { couldn't replicate his early } \\
\text { pace on the second bike, } \\
\text { allowing Marquez to escape } \\
\text { and bringing the Yamaha } \\
\text { rider into a fierce duel for } \\
\text { the runner-up spot. }\end{array}$ \\
\hline
\end{tabular}

If we analyze those sentences by using the competition frame elements and adapted the FrameNet theory, they are analysed as follow:

1. [Valentino Rossi] participant__ was left lamenting a lack of feeling on his second bike that left him powerless to stop [MotoGP] $]_{\text {competition }}$ rival [Marc Marquez] participant_2 romping to victory in $[\text { Argentina }]_{\text {place }}$.

2. With the weekend's tyre drama causing the [Termas de Rio Hondo] venue race to be split in two parts by a mandatory bike swap, [Rossi's race] participant_1 ended up being one of two halves.

3. In the opening phase, [he] participant_1 had the pace to keep up with [Marquez] participant_2, and made his pit stop right on the Spaniard's tail after battling hard for several laps.

Those examples have shown that every sentence related in sport has at least one competition element. None of the sentences on the findings has all of the competition elements. If we make them into percentage, it is shown that the participant competition 
element has got the most frequent appearence than the other element with the percentage of __ $\%$. The formula to count them is as follow:

$$
\begin{aligned}
& \quad \mathbf{P}=\mathbf{F} / \mathbf{N} \mathbf{X} \mathbf{1 0 0 \%} \\
& \mathrm{P}=\text { Percentage } \\
& \mathrm{F}=\text { Frequent of sentences } \\
& \mathrm{N}=\text { Total of sentences }
\end{aligned}
$$

\begin{tabular}{|l|l|l|l|l|l|l|}
\hline \multirow{2}{*}{ Article } & \multicolumn{5}{|c|}{ Sentences consist of: } \\
\cline { 2 - 8 } & Competition & Participant & Place & Prize & Rank\&Score & Venue \\
\hline 1 & 3 & 14 & 2 & 0 & 5 & 3 \\
\hline 2 & 1 & 13 & 1 & 0 & 3 & 1 \\
\hline 3 & 1 & 12 & 1 & 0 & 4 & 1 \\
\hline Total\% & $\begin{array}{l}5 / 42 * 100= \\
\mathbf{1 1 . 9 \%}\end{array}$ & $\begin{array}{l}39 / 42 * 100= \\
\mathbf{9 2 . 8 5 \%}\end{array}$ & $\begin{array}{l}4 / 42 * 100= \\
\mathbf{9 . 5 \%}\end{array}$ & $\begin{array}{l}0 / 42 * 100= \\
\mathbf{0 \%}\end{array}$ & $\mathbf{2 8 . 5 7 \%}$ & $\mathbf{1 1 . 9 \%}$ \\
\hline
\end{tabular}

Based on the analysis above, we can see that the participant element has the most frequent appearance on the articles with the percentage of $\mathbf{9 2 . 8 5 \%}$.

\section{CONCLUSION}

Based on this research, we can conclude that frames are induced when words are comprehended and several words underline certain fragments of a frame. For example, in most MotoGP articles, the most frequent words that occur are dominated on the participant elements (92.85\%) and rank and score elements (28.57\%). In addition, frames induce a certain point of view on a state and propose a certain history in a concept. Moreover, frames often suppose larger cultural which consist of representations of causal and relational information about objects, scenes, and events. 


\section{REFERENCES}

Alshehri, Ali M. (2014). The frame semantics of 'selfmotion' frame in Arabic and English. San Fransisco: San Fransisco State University

Citraresmana, Elvi. (2016). Module cognitive linguistics. Bandung: Universitas Padjajaran

Evans and Green. (2006). Cognitive linguistics: an introduction. Edinburgh: Edinburgh University Press

Fillmore, C. (1976). Frame semantics and the nature of language. Annals of the New York Academy of Sciences, 280 (1 Origins and E), 20-32.

Fillmore and Baker. (2009). A frames approach to semantic analysis.

Fried and Nikiforidou. (2013). Advances in frame semantics. Amsterdam: John S. Benjamins Publishing Company

Hasegawa, Y., Lee-Goldman, R., Kong, A \& Akita, K. (2013). FrameNet as a resource for paraphrase research. In Advances in Frame Semantics, 124-125, Amsterdam: John Benjamin Publishing Company

Lakoff, George. (2014). Charles Fillmore, discoverer of frame semantics, dies in SF at 84: he figured out how framing works. Retrieved 24 April 2016 from https://georgelakoff.com/2014/02/18/charles-fillmore-discoverer-of-framesemantics-dies-in-sf-at-84-he-figured-out-how-framing-works/

Kovecses, Zoltan. (2006). Language, mind, and culture: a practical introduction. United Kingdom: Oxford University Press

Petruck, M. (1997). Frame semantics. Handbook of Pragmatics: 1996 Installment, 113 separately paginated. 